\title{
Simple and Convenient Synthesis of Esters from Carboxylic Acids and Alkyl Halides Using Tetrabutylammonium Fluoride
}

\author{
Kouichi Matsumoto ${ }^{1 *}$, Hayato Shimazaki ${ }^{1}, Y_{\text {Y Miyamoto }}{ }^{1}$, Kazuaki Shimada ${ }^{1}$, \\ Fumi Haga ${ }^{1}$, Yuki Yamada ${ }^{1}$, Hirotsugu Miyazawa ${ }^{2}$, Keiji Nishiwaki ${ }^{2}$ and \\ Shigenori Kashimura ${ }^{1}$

\footnotetext{
${ }^{1}$ Faculty of Science and Engineering, Kinki University (3-4-1 Kowakae, Higashi-Osaka, Osaka 577-8502, JAPAN)
} \\ ${ }^{2}$ Faculty of Pharmacy, Kinki University (3-4-1 Kowakae, Higashi-Osaka, Osaka 577-8502, JAPAN)
}

\begin{abstract}
A simple and convenient method has been developed for the synthesis of esters from the corresponding carboxylic acids and alkyl halides by using a stoichiometric amount of tetrabutylammonium fluoride $\left(\mathrm{Bu}_{4} \mathrm{NF}\right)$ as the base. The reaction of carboxylic acids and a $\mathrm{Bu}_{4} \mathrm{NF} / \mathrm{THF}$ solution in DMF or THF as the solvent generates carboxylate ions in situ. The carboxylate ions thus generated and accumulated are highly reactive. They are then allowed to react with alkyl halides as the electrophiles, and afford the corresponding esters in moderate to good yields. The reaction without $\mathrm{Bu}_{4} \mathrm{NF}$ does not afford any product; therefore, $\mathrm{Bu}_{4} \mathrm{NF}$ seems to play an important role as the base in these reactions. A bulky countercation such as the tetrabutylammonium cation seems to increase the reactivity of the carboxylate ions in the solution phase.
\end{abstract}

Key words: tetrabutylammonium fluoride, base, deprotonation, carboxylate ion, esterification

\section{INTRODUCTION}

Esters are one of the most important functional groups in organic chemistry, and are present in several organic compounds such as biologically active molecules and compounds relevant to materials chemistry. For ester synthesis, condensation reactions have mainly been employed, in which carboxylic acids and alcohols are combined in the presence of acid catalysts such as Brønsted acids. In addition, efficient esterification methods have been developed using orthoesters, condensation reagents such as $N, N^{\prime}$-dicyclohexylcarbodiimide, $N, N^{\prime}$-diisopropylcarbodiimide, and diazomethane $e^{1-4)}$.

A more straightforward method involving the reaction of carboxylate ions and alkyl halides via an $\mathrm{S}_{\mathrm{N}} 2$ mechanism seems to be an attractive procedure for constructing ester group $^{5-20)}$. Maruoka and co-workers reported that the reaction of trialkylsilyl esters and alkyl halides in the presence of $\mathrm{Bu}_{4} \mathrm{NF} \cdot \mathrm{H}_{2} \mathrm{O}$ affords the corresponding esters, owing to the affinity of the fluoride ion(derived from
$\mathrm{Bu}_{4} \mathrm{NF}$ ) for the silicon atom ${ }^{21,22)}$. Although the resulting ammonium carboxylates ${ }^{23-30)}$ seem to be attractive from the viewpoint of reactivity, this protocol involves an additional step of preparing the trialkylsilyl esters from the carboxylic acids. These authors also demonstrated the esterification of carboxylic acids and alkyl halides using $\mathrm{Bu}_{4} \mathrm{NF}$ generated in situ from $\mathrm{KF} \cdot 2 \mathrm{H}_{2} \mathrm{O}$ and a catalytic amount of $\mathrm{Bu}_{4} \mathrm{NHSO}_{4}$ under solid-liquid phase-transfer conditions ${ }^{31 \text {. }}$. The reaction yields are high and the procedure is simple, but a long reaction time (3-24 h) and an excess amount of $\mathrm{KF} \cdot 2 \mathrm{H}_{2} \mathrm{O}$ are required.

To the best of our knowledge, the esterification of carboxylic acids and alkyl halides using a stoichiometric amount of $\mathrm{Bu}_{4} \mathrm{NF}$ as a base has not been reported. Herein, we demonstrate that a stoichiometric amount of $\mathrm{Bu}_{4} \mathrm{NF}$ serves as a useful base in the deprotonation of the carboxylic acids, and the ammonium carboxylates thus generated can react with alkyl halides to afford the corresponding esters in good yields (Scheme 1). This procedure shortens

*Correspondence to: Kouichi Matsumoto, Faculty of Science and Engineering, Kinki University, 3-4-1 Kowakae, Higashi-Osaka, Osaka 577-8502, JAPAN

E-mail: kmatsumo@chem.kindai.ac.jp

Accepted March 6, 2014 (received for review November 19, 2013)

Journal of Oleo Science ISSN 1345-8957 print / ISSN 1347-3352 online

http://www.jstage.jst.go.jp/browse/jos/ http://mc.manusriptcentral.com/jjocs 


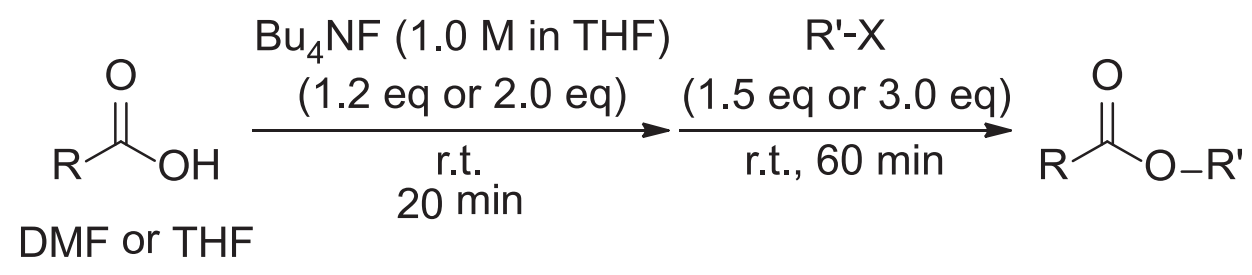

Scheme 1 Esterification of carboxylic acids and alkyl halides using a stoichiometric amount of $\mathrm{Bu}_{4} \mathrm{NF}$.

the reaction time required, and simplifies and facilitates the synthesis of various esters.

\section{EXPERIMENTAL PROCEDURES}

\subsection{General Remarks}

${ }^{1} \mathrm{H}$ and ${ }^{13} \mathrm{C}$ NMR spectra were recorded in $\mathrm{CDCl}_{3}$ on a Varian MERCURY $300\left({ }^{1} \mathrm{H}, 300 \mathrm{MHz} ;{ }^{13} \mathrm{C}, 75 \mathrm{MHz}\right)$ or JEOL-AL $400\left({ }^{1} \mathrm{H}, 400 \mathrm{MHz} ;{ }^{13} \mathrm{C}, 100 \mathrm{MHz}\right)$ spectrometer with $\mathrm{Me}_{4} \mathrm{Si}$ as an internal standard unless otherwise noted. Mass spectra were obtained on JEOL JMS SX-102A(EI) and Thermo Fisher Scientific EXACTIVE(APCI and ESI) mass spectrometers. Thin-layer chromatography (TLC) was performed by using Merck precoated silica gel F254 plates (thickness $0.25 \mathrm{~mm}$ ). Flash chromatography was carried out on a column of silica gel (Kanto Chem. Co., Silica Gel N, spherical, neutral, 40-100 $\mu \mathrm{m}$ ). Preparative gel permeation chromatography (GPC) was performed on a Japan Analytical Industry LC-9201 instrument equipped with JAIGEL$1 \mathrm{H}$ and JAIGEL-2H, using $\mathrm{CHCl}_{3}$ as an eluent. All reactions were carried out under a nitrogen atmosphere unless otherwise noted.

\subsection{Materials}

Unless otherwise noted, all materials, including dry THF, dry DMF, carboxylic acids, alkyl halides, and $\mathrm{Bu}_{4} \mathrm{NF}(1.0 \mathrm{M}$ in THF), were obtained from commercial suppliers and used without further purification.

\subsection{Reaction of carboxylic acid and alkyl halide}

Typical procedure for the reaction of benzoic acid (1) and $n$-butyl iodide ( $n$-BuI) using $\mathrm{Bu}_{4} \mathrm{NF}$ (1.0 M in THF) solution. $n$-Butyl benzoate (2) (condition A): $\mathrm{Bu}_{4} \mathrm{NF}(1.0 \mathrm{M}$ in THF, $1.2 \mathrm{~mL}, 1.2 \mathrm{mmol}$ ) was added at room temperature to a solution of benzoic acid (1, $121.9 \mathrm{mg}, 1.0 \mathrm{mmol})$ in $\mathrm{DMF}(1.0$ $\mathrm{mL}$ ), and the mixture was stirred for $20 \mathrm{~min}$. Then, the solution was allowed to react with $n$-butyl iodide ( $n$-BuI) (281.6 mg, $1.5 \mathrm{mmol}$ ) for $60 \mathrm{~min}$ at the same temperature. Subsequently, water $(5.0 \mathrm{~mL})$ was added to the resulting solution, and the aqueous phase was extracted with $\mathrm{Et}_{2} \mathrm{O}$ $(15 \mathrm{~mL} \times 3)$. The combined organic extracts were washed with saturated aqueous $\mathrm{NaCl}$ solution $(20 \mathrm{~mL})$ and dried over $\mathrm{Na}_{2} \mathrm{SO}_{4}$. After removal of the solvent, the resulting crude product was purified by flash chromatography (hexane/EtOAc 20:1) to obtain $n$-butyl benzoate(2) (99.7 $\mathrm{mg}, 0.56 \mathrm{mmol}, 56 \%)$. The product was identified through the comparison of its spectral data with that of reported literature $^{32)}$.

\subsection{Spectroscopic data}

Isopropyl nonanoate (10)

${ }^{1} \mathrm{H} \mathrm{NMR}\left(300 \mathrm{MHz}, \mathrm{CDCl}_{3}\right) \delta 0.88(\mathrm{t}, J=6.6 \mathrm{~Hz}, 3 \mathrm{H}), 1.23$ (d, $J=6.3 \mathrm{~Hz}, 6 \mathrm{H}), 1.24-1.36(\mathrm{~m}, 9 \mathrm{H}), 1.54-1.66(\mathrm{~m}, 2 \mathrm{H})$, $2.26(\mathrm{t}, J=7.5 \mathrm{~Hz}, 2 \mathrm{H}), 5.00$ (septet, $J=6.3 \mathrm{~Hz}, 1 \mathrm{H}) ;{ }^{13} \mathrm{C}$ $\operatorname{NMR}\left(75 \mathrm{MHz}, \mathrm{CDCl}_{3}\right) \delta 14.1,21.8,22.6,25.0,29.1,29.2$, $31.8,34.7,67.3,173.5$ (The one signal in ${ }^{13} \mathrm{C}$ NMR might be overlapping. See also the supporting information of ref 33)); $\operatorname{LRMS}($ APCI $) \mathrm{m} / \mathrm{z} 201\left(\mathrm{M}^{+}+\mathrm{H}\right)$; HRMS (APCI) calcd for $\mathrm{C}_{12} \mathrm{H}_{25} \mathrm{O}_{2}\left(\mathrm{M}^{+}+\mathrm{H}\right) 201.1849$, found 201.1848.

Isopropyl cinnamate (12)

${ }^{1} \mathrm{H} \mathrm{NMR}\left(400 \mathrm{MHz}, \mathrm{CDCl}_{3}\right) \delta 1.32(\mathrm{~d}, J=6.3 \mathrm{~Hz}, 6 \mathrm{H}), 5.14$ (septet, $J=6.3 \mathrm{~Hz}, 1 \mathrm{H}), 6.41$ (d, $J=16.1 \mathrm{~Hz}, 1 \mathrm{H}$ ), 7.35-7.41 $(\mathrm{m}, 3 \mathrm{H}), 7.48-7.55(\mathrm{~m}, 2 \mathrm{H}), 7.66(\mathrm{~d}, J=16.1 \mathrm{~Hz}, 1 \mathrm{H}) ;{ }^{13} \mathrm{C}$ $\operatorname{NMR}\left(100 \mathrm{MHz}, \mathrm{CDCl}_{3}\right) \delta 21.9,67.8,118.8,128.0,128.8$, 130.1, 134.5, 144.3, 166.5; LRMS (EI) m/z $190\left(\mathrm{M}^{+}\right), 131\left(\mathrm{M}^{+}\right.$ $\left.-\mathrm{C}_{3} \mathrm{H}_{7} \mathrm{O}\right)$; HRMS (EI) calcd for $\mathrm{C}_{12} \mathrm{H}_{14} \mathrm{O}_{2}\left(\mathrm{M}^{+}\right)$190.0994, found 190.0999 .

(E)-Isopropyl 3- (4-methoxyphenyl) acrylate (15)

${ }^{1} \mathrm{H} \mathrm{NMR}\left(400 \mathrm{MHz}, \mathrm{CDCl}_{3}\right) \delta 1.30(\mathrm{~d}, J=6.3 \mathrm{~Hz}, 6 \mathrm{H}), 5.13$ (septet, $J=6.3 \mathrm{~Hz}, 1 \mathrm{H}), 6.28(\mathrm{~d}, J=15.9 \mathrm{~Hz}, 1 \mathrm{H}), 6.89$ (d, $J$ $=8.8 \mathrm{~Hz}, 1 \mathrm{H}), 7.46(\mathrm{~d}, J=8.8 \mathrm{~Hz}, 1 \mathrm{H}), 7.62(\mathrm{~d}, J=15.9 \mathrm{~Hz}$, $1 \mathrm{H}) ;{ }^{13} \mathrm{C} \mathrm{NMR}\left(100 \mathrm{MHz}, \mathrm{CDCl}_{3}\right) \delta 21.9,55.3,67.5,114.3$, 116.3, 127.3, 129.6, 143.9, 161.3, 166.8; LRMS(EI) m/z 220 $\left(\mathrm{M}^{+}\right), 161\left(\mathrm{M}^{+}-\mathrm{C}_{3} \mathrm{H}_{7} \mathrm{O}\right)$; HRMS (EI) calcd for $\mathrm{C}_{13} \mathrm{H}_{16} \mathrm{O}_{3}\left(\mathrm{M}^{+}\right)$ 220.1099 , found 220.1103 .

(E) -Isopropyl 3-(3-methoxyphenyl) acrylate (17)

${ }^{1} \mathrm{H} \mathrm{NMR}\left(400 \mathrm{MHz}, \mathrm{CDCl}_{3}\right) \delta 1.31(\mathrm{~d}, J=6.3 \mathrm{~Hz}, 6 \mathrm{H}), 5.14$ (septet, $J=6.3 \mathrm{~Hz}, 1 \mathrm{H}), 6.40(\mathrm{~d}, J=16.1 \mathrm{~Hz}, 1 \mathrm{H}), 6.92(\mathrm{dd}$, $J=8.3,2.0 \mathrm{~Hz}, 1 \mathrm{H}), 7.04(\mathrm{t}, J=2.0 \mathrm{~Hz}, 1 \mathrm{H}), 7.11(\mathrm{dd}, J=$ $8.3,0.5 \mathrm{~Hz}, 1 \mathrm{H}), 7.29(\mathrm{t}, J=8.3 \mathrm{~Hz}, 1 \mathrm{H}), 7.63(\mathrm{~d}, J=16.1$ $\mathrm{Hz}, 1 \mathrm{H}) ;{ }^{13} \mathrm{C} \mathrm{NMR}\left(100 \mathrm{MHz}, \mathrm{CDCl}_{3}\right) \delta 21.9,55.2,67.8$, 112.8, 116.0, 119.1, 120.7, 129.8, 135.9, 144.2, 159.9, 166.4; $\operatorname{LRMS}(\mathrm{EI}) \mathrm{m} / \mathrm{z} 220\left(\mathrm{M}^{+}\right), 161\left(\mathrm{M}^{+}-\mathrm{C}_{3} \mathrm{H}_{7} \mathrm{O}\right) ; \operatorname{HRMS}(\mathrm{EI})$ calcd for $\mathrm{C}_{13} \mathrm{H}_{16} \mathrm{O}_{3}\left(\mathrm{M}^{+}\right) 220.1099$, found 220.1094.

Isopropyl 1-naphthoate (19)

${ }^{1} \mathrm{H} \mathrm{NMR}\left(400 \mathrm{MHz} \mathrm{CDCl}_{3}\right) \delta 1.44(\mathrm{~d}, J=6.3 \mathrm{~Hz}, 6 \mathrm{H}), 5.37$ (septet, $J=6.3 \mathrm{~Hz}, 1 \mathrm{H}), 7.48(\mathrm{t}, J=7.1 \mathrm{~Hz}, 1 \mathrm{H}), 7.51(\mathrm{t}, J=$ $7.1 \mathrm{~Hz}, 1 \mathrm{H}), 7.60(\mathrm{t}, J=8.3 \mathrm{~Hz}, 1 \mathrm{H}), 7.86(\mathrm{~d}, J=8.3 \mathrm{~Hz}$, $1 \mathrm{H}), 7.99(\mathrm{~d}, J=8.3 \mathrm{~Hz}, 1 \mathrm{H}), 8.14(\mathrm{~d}, J=7.1 \mathrm{~Hz}, 1 \mathrm{H}), 8.88$ $(\mathrm{d}, J=8.3 \mathrm{~Hz}, 1 \mathrm{H}) ;{ }^{13} \mathrm{C} \mathrm{NMR}\left(100 \mathrm{MHz}, \mathrm{CDCl}_{3}\right) \delta 22.0,68.5$, 124.5, 125.8, 126.1, 127.6, 128.0, 128.5, 129.8, 131.3, 133.0, 
133.8, 167.2; LRMS (EI) m/z $214\left(\mathrm{M}^{+}\right), 155\left(\mathrm{M}^{+}-\mathrm{C}_{3} \mathrm{H}_{7} \mathrm{O}\right)$; $\operatorname{HRMS}$ (EI) calcd for $\mathrm{C}_{14} \mathrm{H}_{14} \mathrm{O}_{2}\left(\mathrm{M}^{+}\right) 214.0994$, found 214.0995.

Isopropyl 2- (4-methylbenzoyl) benzoate (21)

${ }^{1} \mathrm{H} \mathrm{NMR}\left(400 \mathrm{MHz}, \mathrm{CDCl}_{3}\right) \delta 1.03(\mathrm{~d}, J=6.1 \mathrm{~Hz}, 6 \mathrm{H}), 2.40$ $(\mathrm{s}, 3 \mathrm{H}), 4.99$ (septet, $J=6.1 \mathrm{~Hz}, 1 \mathrm{H}), 7.22(\mathrm{~d}, J=8.0 \mathrm{~Hz}$, $2 \mathrm{H}), 7.35(\mathrm{~d}, J=7.6 \mathrm{~Hz}, 1 \mathrm{H}), 7.54(\mathrm{t}, J=7.6 \mathrm{~Hz}, 1 \mathrm{H}), 7.61$ (t, $J=7.6 \mathrm{~Hz}, 1 \mathrm{H}), 7.66(\mathrm{~d}, J=8.0 \mathrm{~Hz}, 1 \mathrm{H}), 8.06$ (d, $J=7.6$ $\mathrm{Hz}, 1 \mathrm{H}) ;{ }^{13} \mathrm{C} \mathrm{NMR}\left(100 \mathrm{MHz}, \mathrm{CDCl}_{3}\right) \delta 21.2,21.6,69.4$, 127.5, 129.1, 129.3, 129.6, 129.7, 130.1, 132.1, 134.8, 141.8, 143.9, 165.4, 196.6; LRMS (EI) m/z $282\left(\mathrm{M}^{+}\right), 223\left(\mathrm{M}^{+}-\right.$ $\left.\mathrm{C}_{3} \mathrm{H}_{7} \mathrm{O}\right)$; HRMS (EI) calcd for $\mathrm{C}_{18} \mathrm{H}_{18} \mathrm{O}_{3}\left(\mathrm{M}^{+}\right) 282.1256$, found 282.1252 .

(E)-Diphenethyl hex-3-enedioate (23)

${ }^{1} \mathrm{H} \mathrm{NMR}\left(400 \mathrm{MHz}, \mathrm{CDCl}_{3}\right) \delta 2.93(\mathrm{t}, J=7.1 \mathrm{~Hz}, 4 \mathrm{H}), 3.05$ $(\mathrm{d}, J=5.1 \mathrm{~Hz}, 4 \mathrm{H}), 4.30(\mathrm{t}, J=7.1 \mathrm{~Hz}, 4 \mathrm{H}), 5.60-5.66(\mathrm{~m}$, 2H), 7.18-7.33 (m, 10H); ${ }^{13} \mathrm{C} \mathrm{NMR}\left(100 \mathrm{MHz}, \mathrm{CDCl}_{3}\right) \delta 35.0$, 37.8, 65.1, 76.7, 125.9, 126.5, 128.5, 128.9, 137.7, 171.4; LRMS (APCI) m/z $353\left(\mathrm{M}^{+}+\mathrm{H}\right)$; HRMS (APCI) calcd for $\mathrm{C}_{22} \mathrm{H}_{25} \mathrm{O}_{4}\left(\mathrm{M}^{+}+\mathrm{H}\right) 353.1747$, found 353.1736.

Other compounds such as methyl benzoate $(3)^{32)}, n$-octyl benzoate $(4)^{32)}$, isopropyl benzoate $(5)^{34)}, n$-butyl 3-phenylpropanoate $(\mathbf{7})^{35)}$, and isopropyl 3-phenylpropanoate $(\mathbf{8})^{36)}$, were identified through the comparison of its spectral data with those of reported literatures.

\section{RESULTS AND DISCUSSION}

In preliminary studies, we examined the reaction of benzoic acid(1) with 1.5 equivalents of $n$-butyl iodide $\left(n\right.$-BuI) in DMF using 1.2 equivalents of $\mathrm{Bu}_{4} \mathrm{NF}(1.0 \mathrm{M}$ in THF) (Table 1, condition A). The usual workup procedure and flash column chromatography afforded the corresponding ester ( $n$-butyl benzoate (2)) in 56\% yield as shown in Table 1 (only the isolated yields of esters are listed; the conversions were not determined). In contrast, in the absence of $\mathrm{Bu}_{4} \mathrm{NF}$, no product was obtained from the reaction of 1 and $n$-BuI, indicating that $\mathrm{Bu}_{4} \mathrm{NF}$ is essential for the esterification of carboxylic acids with alkyl halides. Therefore, it is concluded that $\mathrm{Bu}_{4} \mathrm{NF}$ itself plays two important roles in this esterification: first, the $\mathrm{F}^{-}$anion derived from $\mathrm{Bu}_{4} \mathrm{NF}$ serves as an effective base for the deprotonation of the carboxylic acid; and second, the resulting $\mathrm{Bu}_{4} \mathrm{~N}^{+}$carboxylates are partially soluble in organic media; therefore, the reaction of the carboxylates with alkyl halides via the $\mathrm{S}_{\mathrm{N}} 2$ mechanism would be accelerated ${ }^{21,23,31)}$. Other alkyl halides such as $n$-butyl bromide $(n$-BuBr), methyl iodide (MeI), $n$-octyl iodide ( $n$-OctI), and isopropyl iodide $(i$-PrI $)$ were also used for the esterification of benzoic acid to afford the corresponding products $(2,3,4$, and 5$)$ in $42 \%, 44 \%, 68 \%$, and $32 \%$ yields, respectively.

The esterification reactions of other carboxylic acids were also examined under condition A. As shown in Table 1, 3-phenylpropanoic acid (6) was treated with $n$-BuI and $i$-PrI to form 7 and 8 , respectively. In addition, nonanoic $\operatorname{acid}(9)$, cinnamic acid (11), (E)-3-(4-methoxyphenyl) acrylic acid (14), (E)-3-(3-methoxyphenyl)acrylic acid (16) , and 1-naphthoic acid (18) afforded the corresponding esters 10, 12, 15, 17, and 19, respectively, in moderate yields; however, the reaction of 11 with 2-chlorobutane did not proceed at all, presumably because of the low reactivity of 2-chlorobutane. It is noteworthy that the reaction of 2(4-methylbenzoyl) benzoic acid (20) afforded the corresponding ester 21 in $55 \%$ yield, and that the fluoride ion did not attack the carbonyl group.

We suspected that the first step of this esterification, that is, the deprotonation of the acid, would be rate-controlling, because the longer reaction time of 1 afforeded a higher yield of 2 (74\% yield, Table 1, condition A). Therefore, we modified the reaction conditions in order to accelerate the reactions, and used two equivalents of $\mathrm{Bu}_{4} \mathrm{NF}$ (1.0 $\mathrm{M}$ in THF) and three equivalents of the alkyl halide (Table 1, condition $\mathrm{B}$ ). The reaction of 1 and $n$-BuI for $60 \mathrm{~min}$ afforded the product in $95 \%$ yield (quantitative yield from ${ }^{1} \mathrm{H}$ NMR of crude product). For the reaction of the carboxylate ions with alkyl halides, we also examined the effect of reaction time. The reactions for 5 and 10 min with $n$-BuI afforded the products in $76 \%$ and $94 \%$ yields $\left({ }^{1} \mathrm{H}\right.$ NMR yields of crude products), respectively, indicating that the reaction proceeded more rapidly than under condition A. Furthermore, as seen in Table 1, the reactions proceeded smoothly and afforded the corresponding products in good yields in all other cases. In view of the successful results obtained here, esterification reactions using THF as the solvent instead of DMF under condition B were also examined (Table 1, condition $\mathrm{C}$ ). This protocol was also found to be effective for the synthesis of esters from carboxylic acids and alkyl halides. However, in some cases, the reaction yields decreased. For example, the reaction of 18 and $i$-PrI afforded the product in $22 \%$ yield, together with the recovery of 18 in approximately $75 \%$ yield. These results might be caused by the low solubility of the carboxylic acids of starting materials in THF.

Finally, this method was successfully applied to the diesterification reaction(Scheme 2). $\mathrm{Bu}_{4} \mathrm{NF}(1.0 \mathrm{M}$ in THF, 4.0 $\mathrm{mL}, 4.0 \mathrm{mmol}$ ) was added to a solution of $(E)$-hex-3-enedioic $\operatorname{acid}(22)(1.0 \mathrm{mmol})$ in $\operatorname{DMF}(1.0 \mathrm{~mL})$ or $\operatorname{THF}(1.0 \mathrm{~mL})$. Then, the resulting solution was allowed to react with (2-bromoethyl) benzene (6.0 mmol) for $60 \mathrm{~min}$, and the corresponding product 23 was obtained in $45 \%$ yield in DMF and $36 \%$ yield in $\mathrm{THF}^{37)}$.

\section{CONCLUSION}

In summary, the reaction of carboxylic acids with the 
K. Matsumoto, H. Shimazaki, Y. Miyamoto et al.

Table 1 Reaction of carboxylic acids and alkyl halides using $\mathrm{Bu}_{4} \mathrm{NF}$ as the base.

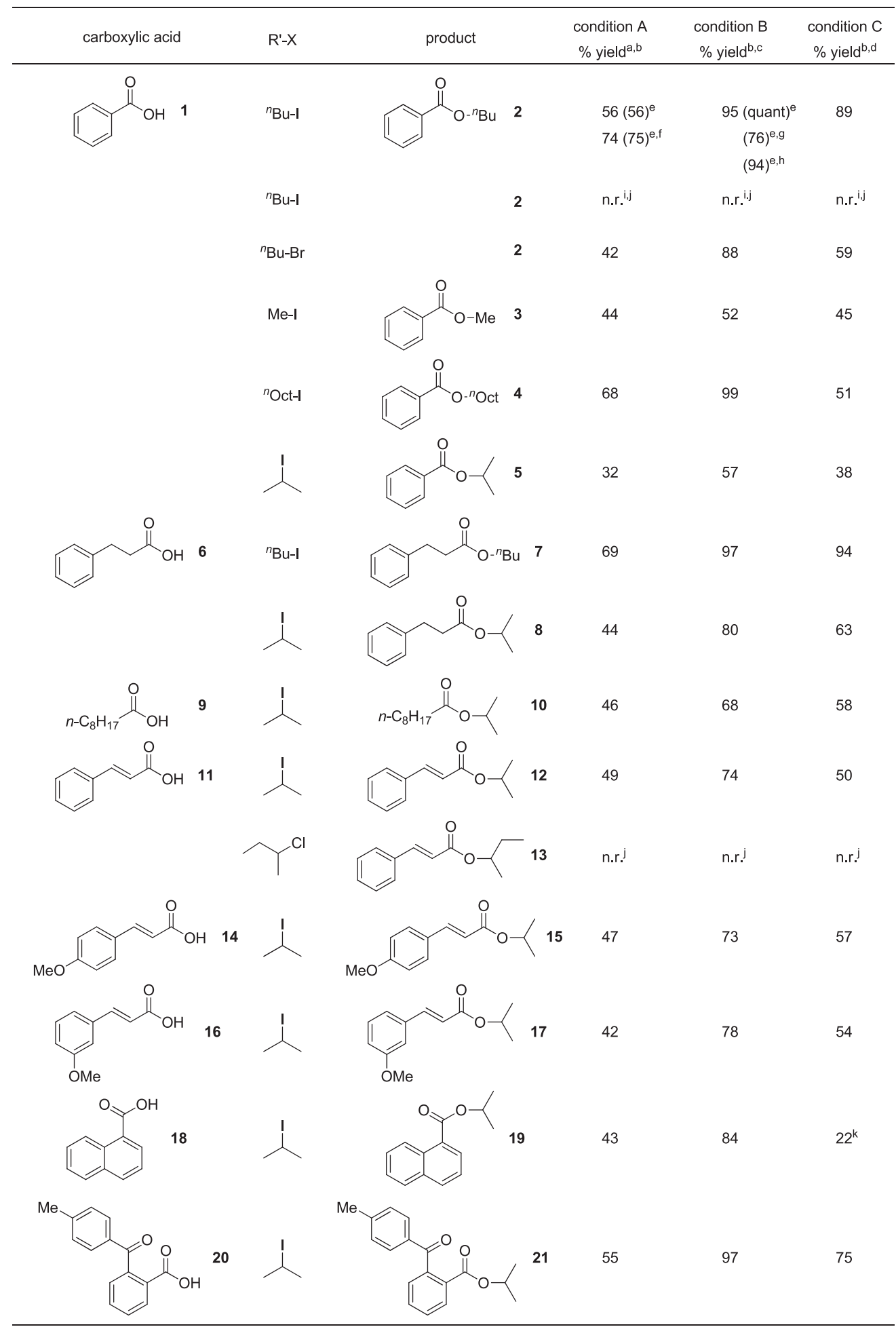

${ }^{\text {a }}$ Typical procedure (condition A): $\mathrm{Bu}_{4} \mathrm{NF}(1.0 \mathrm{M}$ in THF, $1.2 \mathrm{~mL}, 1.2 \mathrm{mmol}$ ) was added at room temperature to a solution of carboxylic acid (1.0 mmol) in DMF $(1.0 \mathrm{~mL})$, and the mixture was stirred for $20 \mathrm{~min}$. Then, the solution was allowed to react with R'-X $(1.5 \mathrm{mmol})$ for $60 \mathrm{~min}$ at the same temperature. Subsequently, water $(5.0 \mathrm{~mL})$ was added to the resulting solution. ${ }^{b}$ Isolated yields. ${ }^{\circ}$ Condition B: DMF $(1.0 \mathrm{~mL})$ as the solvent, $\mathrm{Bu} 4 \mathrm{NF}(1.0 \mathrm{M}$ in THF, $2.0 \mathrm{~mL}, 2.0 \mathrm{mmol})$ and R'-X $(3.0 \mathrm{mmol})$ were used. The reaction time was same. ${ }^{\mathrm{d}}$ Condition C: THF $(1.0 \mathrm{~mL})$ as the solvent, $\mathrm{Bu}_{4} \mathrm{NF}(1.0 \mathrm{M}$ in THF, $2.0 \mathrm{~mL}, 2.0 \mathrm{mmol})$ and R'-X (3.0 mmol) were used. The reaction time was same. ${ }^{e}$ Yield in parenthesis is ${ }^{1} \mathrm{H}$ NMR yield of the crude product. ${ }^{f}$ The reaction time of 1 and $\mathrm{Bu}_{4} \mathrm{NF}$ was 20 min, and the reaction time with $n$-BuI was $120 \mathrm{~min}^{\mathrm{g}}{ }^{\mathrm{g}}$ The reaction time of $\mathbf{1}$ and $\mathrm{Bu}_{4} \mathrm{NF}$ was $20 \mathrm{~min}$, and the reaction time with $n$-BuI was 5 min. ${ }^{\mathrm{h}}$ The reaction time of $\mathbf{1}$ and $\mathrm{Bu}_{4} \mathrm{NF}$ was $20 \mathrm{~min}$, and the reaction time with $n$-BuI was $10 \mathrm{~min} .{ }^{\mathrm{i}}$ Reaction of benzoic acid (1) and $n$-BuI without $\mathrm{Bu}_{4} \mathrm{NF}$. ${ }^{\mathrm{j}}$ n.r. $=$ no reaction. ${ }^{\mathrm{k}}$ Approximately $75 \%$ of $\mathbf{1 8}$ was recovered. 


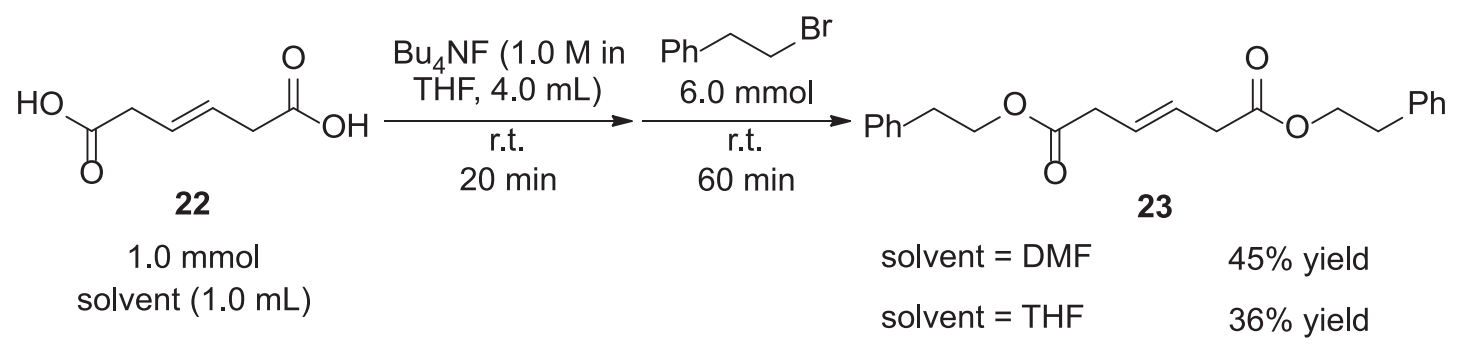

Scheme 2 Diesterification of (E)-hex-3-enedioic acid (22).

$\mathrm{Bu}_{4} \mathrm{NF} / \mathrm{THF}$ reagent proceeded smoothly to generate ammonium carboxylates, which reacted with alkyl halides to afford the corresponding esters in moderate to good yields. In some cases, on the basis of the product yields, DMF seemed to be a better solvent than THF; this might be because of the difference in the solubility of the carboxylic acids in DMF and THF. Diesterification was also demonstrated by using this procedure. The success of this method seems to be due to the high reactivity of carboxylate ions, which might be increased by the bulky tetrabutylammonium countercation $^{21,23,31)}$. This method allows the straightforward synthesis of various esters. Further studies on other types of reactions using $\mathrm{Bu}_{4} \mathrm{NF}$ as a base are in progress in our laboratories.

\section{ACKNOWLEDGMENT}

K.M. is thankful for the financial support from AMANO INSTITUTE OF TECHNOLOGY.

\section{References}

1) Otera, J.; Nishikido, J. Esterification: Methods, Reactions, and Applications, 2nd ed., Wiley-VCH, Weinheim, Germany (2009).

2) Smith, M. B.; March, J. Advanced Organic Chemistry, 5th ed., Wiley, New York (2001).

3) Larock, R. C. Comprehensive Organic Transformations, 2nd ed., Wiley-VCH, New York (1999).

4) For example, Haslam, E. Recent developments in methods for the esterification and protection of the carboxyl group. Tetrahedron 36, 2409-2433 (1980).

5) Some selected reports: ref 5)-20). Dighe, S. N.; Bhattad, R. V.; Kulkarni, R. R.; Jain, K. S.; Srinivasan, K. V. $\mathrm{A}$ rapid and facile esterification of $\mathrm{Na}$-carboxylates with alkyl halides promoted by the synergy of the combined use of DMSO and an ionic liquid under ambient conditions. Synth. Commum. 40, 3522-3527 (2010).

6) Gok, Y.; Alici, B.; Cetinkaya, E.; Ozdemir, I.; Ozeroglu, O. Ionic liquids as solvent for efficient esterification of carboxylic acids with alkyl halides. Turk. J. Chem. 34,
187-191 (2010).

7) Biondini, D.; Brinchi, L.; Germani, R.; Savelli, G. An effective chemoselective esterification of hydroxybenzoic acids in ionic liquids promoted by KF. Lett. Org. Chem. 3, 207-211 (2006).

8) McNulty, J.; Cheekoori, S.; Nair, J. J.; Larichev, V.; Capretta, A.; Robertson, A. A mild esterification process in phosphonium salt ionic liquid. Tetrahedron Lett. 46, 3641-3644(2005).

9) Khan, K. M.; Hayat, S.; Ullah, Z.; Rahman, A.; Choudhary, M. I.; Maharvi, G. M.; Bayer, E. An alternative method for the synthesis of $\gamma$-lactones by using cesium fluoride-celite/acetonitrile combination. Synth. Commum. 33, 3435-3453 (2003).

10) Brinchi, L.; Germani, R.; Savelli, G. Efficient esterification of carboxylic acids with alkyl halides catalyzed by fluoride ions in ionic liquids. Tetrahedron Lett. 44, 6583-6585(2003).

11) Brinchi, L.; Germani, R.; G. Savelli, G. Ionic liquids as reaction media for esterification of carboxylate sodium salts with alkyl halides. Tetrahedron Lett. 44, 20272029 (2003).

12) Judeh, Z. M. A.; Shen, H.; Chi, B. C.; Feng, L.; Selvasothi, S. A facile and efficient nucleophilic displacement reaction at room temperature in ionic liquids. Tetrahedron Lett. 43, 9381-9384(2002).

13) Lee, J. C; Choi, Y. An improved method for preparation of carboxylic esters using CsF-celite/alkyl halide/ $\mathrm{CH}_{3} \mathrm{CN}$ combination. Synth. Commum. 28, 2021-2026 (1998).

14) Lee, J. C.; Oh, Y. S.; Cho, S. H.; Lee, J. Efficient in situ esterification of carboxylic acids using cesium carbonate. Org. Prep. Proced. Int. 28, 480-483(1996).

15) Mehta, G. Convenient preparation of methyl esters from carboxylic acids. Synthesis 262 (1972).

16) Clark, J. H.; Emsle, J.; Hoyte, O. P. A. Reactions of carboxylic acids with dichloro- and dibromo-alkanes in the presence of fluoride ions: Effect of very strong hydrogen bonding. J. Chem. Soc., Perkin Trans. 1, 1091-1094 (1977).

17) Clark, J. H.; Miller, J. M. Hydrogen bonding in organic synthesis. V: Potassium fluoride in carboxylic acids as an alternative to crown ether with acid salts in the preparation of phenacyl esters. Tetrahedron Lett. 18, 
599-602 (1977).

18) Clark, J. H.; Miller, J. M. Hydrogen bonding in organic synthesis. 3. Hydrogen bond assisted reactions of cyclic organic hydrogen bond electron acceptors with halogenoalkanes in the presence of potassium fluoride. J. Am. Chem. Soc. 99, 498-504(1977).

19) Clark, J. H.; Miller, J. M. Hydrogen bonding in organic synthesis; enhanced reactivity of aromatic compounds capable of hydrogen bonding to fluoride. J. Chem. Soc., Chem. Comm. 229-230 (1976).

20) See also, Khan, K. M.; Maharvi, G. M.; Hayat, S.; Ullah, Z.; Choudhary, M. I.; Rahman, A. An expedient esterification of aromatic carboxylic acids using sodium bromate and sodium hydrogen sulfite. Tetrahedron 59, 5549-5554 (2003).

21) Ooi, T.; Sugimoto, H.; Maruoka, K. Facile conversion of trialkylsilyl esters to alkyl esters mediated by tetrabutylammonium fluoride trihydrate. Heterocycles 54, 593-596 (2001).

22) The use of organotin carboxylate. See, Sato, T.; Otera, J.; Nozaki, H. Cesium fluoride-promoted esterification of carboxylic acids. A practical alternative to the diazomethane method and direct conversion of organotin carboxylates. J. Org. Chem. 57, 2166-2169 (1992).

23) We have also reported that the ammonium carboxylate, which was generated by the reaction of carboxylic acids and electrochemically generated 2-pyrrolidone anion, reacts with alkyl halide to afford the esters in good yield. It was found that the reactivity of the resulting ammonium carboxylate depends on the size of countercation in the reaction of the formation of macrolides. See ref 24). See also ref 25)-30).

24) Shono, T.; Ishige, O.; Uyama, H.; Kashimura, S. Electroorganic chemistry. 91. A novel base useful for synthesis of esters and macrolides. J. Org. Chem. 51, 546-549 (1986).

25) Shono, T.; Ishifune, M.; Okada, T.; Kashimura, S. Electroorganic chemistry. 130. A novel trifluoromethylation of aldehydes and ketones promoted by an electrogenerated base. J. Org. Chem. 56, 2-4(1991).

26) Shono, T.; Ishifune, M.; Ishige, O.; Uyama, H.; Kashimura, S. Formation of a reasonably stabilized trichloromethyl anion by the reaction of chloroform with electrogenerated base and its 1,4-addition to $\alpha$, $\beta$-unsaturated carbonyl compounds. Tetrahedron Lett. 31, 7181-7184(1990).

27) Shono, T.; Kashimura, S.; Sawamura, M.; Soejima, T.
Electroorganic chemistry. 103. Selective C-alkylation of $\beta$-diketones. J. Org. Chem. 53, 907-910 (1988).

28) Shono, T.; Kashimura, S.; Nogusa, H. Electroorganic chemistry. 95. Electroreductive N-alkylation of amides, carbamates, and nitrogen-heterocycles. Chem. Lett. 425-428 (1986).

29) Shono, T.; Kashimura, S.; Nogusa, H. A novel electrogenerated base. Alkylation of methyl arylacetates at the $\alpha$-methylene group. J. Org. Chem. 49, 2043-2045 (1984).

30) Shono, T.; Kashimura, S.; Ishizaki, K.; Ishige, O. Electroorganic chemistry. 75. A new electrogenerated base. Condensation of chloroform with aliphatic aldehydes. Chem. Lett. 1311-1312 (1983).

31) Ooi, T.; Sugimoto, H.; Doda, K.; Maruoka, K. Esterification of carboxylic acids catalyzed by in situ generated tetraalkylammonium fluorides. Tetrahedron Lett. 42 , 9245-9248(2001).

32) Liu, C.; Wang, J.; Meng, L.; Deng, Y.; Li, Y.; Lei, A. Palladium-catalyzed aerobic oxidative direct esterification of alcohols. Angew. Chem., Int. Ed. 50, 5144-5148 (2011).

33) Fisher, T. J.; Dussault, P. H. Fragmentation of chloroperoxides: hypochlorite-mediated dehydration of hydroperoxyacetals to esters. Tetrahedron Lett. 51, 5615-5617 (2010).

34) Travis, B. R.; Sivakumar, M.; Hollist, G. O.; Borhan, B. Facile oxidation of aldehydes to acids and esters with oxone. Org. Lett. 5, 1031-1034(2003).

35) Zhao, Y.; Jin, L.; Li, P.; Lei, A. Palladium-catalyzed oxidative carbonylation of alkyl and aryl indium reagents with CO under mild conditions. J. Am. Chem. Soc. 130, 9429-9433 (2008).

36) Tschaen. B. A.; Schmink. J. R.; Molander. G. A. Pd-catalyzed aldehyde to ester conversion: A hydrogen transfer approach. Org. Lett. 15, 500-503(2013).

37) The mono-esterification product as by-product was also obtained in $40 \%$ yield in DMF and $47 \%$ in THF, respectively. $(E)$-6-oxo-6-phenethoxyhex-3-enoic acid: ${ }^{1} \mathrm{H} \mathrm{NMR}\left(300 \mathrm{MHz}, \mathrm{CDCl}_{3}\right) \delta 2.94(\mathrm{t}, J=7.0 \mathrm{~Hz}, 2 \mathrm{H})$, $3.08(\mathrm{~d}, J=5.4 \mathrm{~Hz}, 2 \mathrm{H}), 3.13(\mathrm{dd}, J=5.3,1.2 \mathrm{~Hz}, 2 \mathrm{H})$, $4.31(\mathrm{t}, J=7.0 \mathrm{~Hz}, 2 \mathrm{H}), 5.64-5.71(\mathrm{~m}, 2 \mathrm{H}), 7.17-7.35$ $(\mathrm{m}, 5 \mathrm{H}) ;{ }^{13} \mathrm{C} \mathrm{NMR}\left(75 \mathrm{MHz}, \mathrm{CDCl}_{3}\right) \delta 35.0,37.5,37.8$, 65.2, 125.1, 126.4, 126.5, 128.4, 128.9, 171.4, 177.6; LRMS (ESI, negative mode) m/z 247 (M-H, carboxylate ion); HRMS (ESI, negative mode) calcd for $\mathrm{C}_{14} \mathrm{H}_{15} \mathrm{O}_{4}$ (M$\mathrm{H}$, carboxylate ion) 247.0976, found 247.0972. 